\title{
The Effects of the Corporate Governance Quality of Companies on the Price Performance: A New Generation of Panel Data Analysis on the Companies Listed in the Borsa İstanbul Corporate Governance Index
}

\author{
Esin Benhür Aktürk ${ }^{1 *}$, Mustafa Özyeşi1 ${ }^{2}$ \\ ${ }^{1}$ İstanbul Aydın Üniversitesi Yönetim Organizasyon Programı Yerel Yönetimler Bölümü (ORCID: 0000-0001-5756-1042) \\ 2 İstanbul Aydın Üniversitesi İşletme Yönetimi(İngilizce) Bölümü
}

(First received 30 May 2019 and in final form 16 July 2019)

(DOI: $10.31590 /$ ejosat.571948)

ATIF/REFERENCE: Benhür, E. A. \& Özyeşil, M. (2019). The Effects of the Corporate Governance Quality of Companies on the Price Performance: A New Generation of Panel Data Analysis on the Companies Listed in the Borsa İstanbul Corporate Governance Index. European Journal of Science and Technology, (16), 620-630.

\begin{abstract}
In this study; The effects of corporate governance quality assessment notes (corporate governance rating ) of firms traded on Borsa Istanbul on the stock prices of firms were investigated with the help of the New Generation Panel Data Analysis methods of 27 firms using the annual data of 2012-2018 period. The presence of cross-sectional dependence among firms included in the analysis; Breusch and Pagan (1980) were tested by LM test, Pesaran (2004) LM test, Pesaran (2004) CD test and Baltagi, Feng and Kao (2012) LMBC test and it was found that there was a horizontal cross-sectional dependence between firms. Stability of series; Pesaran (2007) was examined with CADF panel unit root test and all series were determined as I (0). The coefficients in the models were estimated by using Westerlund (2007) OLSAdj method and when the corporate governance quality of the firms increased by 1 unit, it was determined that the stock prices would increase by TL 1.13 .

Causality relations between series; Dumitrescu and Hurlin (2012) method was examined and one-way causality relationships were found between firms' corporate governance quality and share prices.
\end{abstract}

Key Words: Corporate Governance Index, Stock Return, Capital Structure, Panel Data Analysis

\section{Introduction}

The concept of corporate governance has gained more importance in the recent years. One of the main reasons for getting this attraction is the problems experienced in the management issues. These problems, which causes the negative financial results in the first place, in later stages are capable of adversely affecting a firm in terms of all business functions and may lead it to bankruptcy. The main reason of scandals such as Worldcom, Enron, Xerox and Global Crossing in the world is the lack of implementation of corporate governance. Because of the importance of these companies in the sector, bankruptcies have negatively affected the whole market. The purpose of this study is to find out the effects of corporate governance quality on stock price performance.

For this purpose, New Generation Panel Data Analysis methods were performed with the annual data of 27 firms for the period of 2012-2018. In the first part of the study, corporate governance concept, corporate governance principles and corporate governance index are explained. Then, the studies in the literature about the subject were examined and detailed information was provided about the panel data analysis. In the analysis part of the study, stock returns were used as independent variables and corporate governance ratings were

\footnotetext{
${ }^{1}$ Corresponding Author: İstanbul Aydın Üniversitesi Yönetim Organizasyon Programı Yerel Yönetimler Bölümü, ORCID: 0000-0001-5756-1042, esinakturk@,aydin.edu.tr
} 
used as independent variables and econometric analyzes were performed. The test results obtained from the analysis are examined and interpreted in this section.

\section{Conceptual Framework}

\subsection{Corporate Governance}

The process of development and change that has been occurring rapidly in this century, created new ideas and approaches in the business management. Corporate governance has become one of the important approaches during this process. Factors such as the development of national and international economies, the progression of commercial relations, the increase of international and national capital pass-through, the decrease observed in the activities of the shareholders and the increasing importance of the decisions of the board of directors have been effective in the emergence of the concept of corporate governance. The reasons for the transformation of corporate governance into such an important issue are the failures of joint management, crises, misconduct, the role of the private sector, the interdependence of the commercial activities of the countries, the change in the competition conditions of the partnerships. In the light of these advances, corporate governance has been discussed in international and national processes and has become popular all over the world (Dinç ve Abdioğlu, 2009:159).

\subsection{Corporate Governance Principles}

Capital Markets Board (CMB) which aims to regulate and monitor to capital markets and was established for this purpose, also published corporate governance principles in 2003 to further improve the corporate governance base for companies and to make Turkish Capital Markets a competitive international global financial markets and revised these principles in 2005. The CMB prepared its activities in line with the principles of the OECD and the principles of other developing countries on the same dates. CMB prepared corporate governance principles of OECD first in 1999 and then revised them in 2005, this has been base for many developing countries which want to prepare these principles (Ertuna \& Tükel, 2008:8).

Among the corporate governance principles first one is Fairness refers to treat all shareholders and employees equally and justly. The principle of fairness includes the protection of the rights of the shareholders, including the foreign shareholders and minority shareholders, and the implementation of the agreements signed. The principle of fairness includes equal and equitable treatment of all stakeholders and protection of their rights. A fair and equitable management practice can be mentioned when firm management approaches through equal treatment to all employees (Öztürk, 2013:24). Another principle is the transparency principle. Transparency is sharing all non-financial and financial information related to businesses except for the information that is not disclosed to the public due to the nature of trade secrets (confidential information), with all stakeholders in a timely, complete, accurate, easy, understandable, interpretable and accessible manner. The principle of transparency is an approach chain that includes the process before and after the operating activity and the process of the continuation of these activities. It is considered as a good corporate governance practice that the companies announce their prior period operational and financial performance to their investors and underline important risks they may face in the future. Thus; performance, risk and target management subjects constitute the basis for transparency and awareness issues for the enterprises and positively affect the perception of the investors (Acungüç, 2017: 21).

The principle of accountability reveals that corporate governance should not only consist of principles but also be accountable. This requirement also covers the post-transaction period and also considers that the board of directors can freely monitor the performance of the firm's top level and ensure the accountability of senior executives to stakeholders. The most important requirement of the accountability principle in corporate governance is the effective and efficient work sharing between the top management and the board of directors. (TKYD and Delolitte, 2006: 5).

The last principle is responsibility principle refers taking responsibility for the works of the company in accordance with the corporate governance. Businesses should not act with the aim of only creating added value or making a profit in making decisions process in order to sustain their lives. Within the framework of changing and developing management thinking and in the context of creating corporate governance, the concept of responsibility awareness has become a remarkable issue. The issue of responsibility is that senior management feels responsibility not only to business partners but also to shareholders, stakeholders and all society. Social ethical values and other moral factors should also be taken into consideration when making decisions in top management or board of directors. With this principle, it has become necessary for the enterprise to ensure that the regulations comply with social values and laws (Demirbaş ve Uyar, 2006: 240).

\subsection{Corporate Governance Index}

The Corporate Governance Index (XKURY) is an index covers enterprises that carry out and perform the Corporate Governance Principles. In this index, a credit rating of 1 to 10 points is made on whether the listed firms except for in the Custody Market and C List apply the Corporate Governance Principles. If the compliance rating of the Corporate Governance Principles is close to 1, it shows that the enterprise is failing to apply Corporate Governance Principles, if it is close to 10 it indicates that the company meets the requirements of the Corporate Governance Principles more powerful. At the meeting of the Board of Directors of Borsa İstanbul on 23.02.2005, it was decided to include enterprises which their compliance rating score is at least 7 or above in this index (except for ones traded in the custody market). In this index, the relation between share price and corporate governance principles compliance score of enterprises are measured. Within the scope of the rating activities conducted in order to comply with the Corporate Governance Principles, in the Capital Markets Board's 8th and 40th communiqués it is demanded that the institutions that will perform the credit 


\section{Avrupa Bilim ve Teknoloji Dergisi}

rating of the partnerships should be evaluated independently, impartially, fairly and classified accordingly. Businesses subject to these principles have a crucial chance to increase trust and credibility of its internal and external stakeholders.

Table 1. Companies Listed in the Corporate Governance Index

\begin{tabular}{|ll|}
\hline Equity Code & Name \\
AKSGY & Akiş Real Estate Investment Trust Inc. \\
AKMGY & Akmerkez Real Estate Investment Trust Inc. \\
AKSA & Aksa Akrilik Chemical Industry Inc. \\
ALBRK & Albaraka Türk Participation Bank Inc. \\
ANSGR & Anadolu Anonim Türk Insurance Company \\
AEFES & Anadolu Efes Brewery and Malt Industry Inc. \\
ARCLK & Arçelik Inc.. \\
ASELS & Aselsan Electronics Industry and Trade Inc. \\
AYGAZ & Aygaz Inc. \\
CCOLA & Coca-Cola Beverage Inc. \\
CRDFA & Creditwest Factoring Inc. \\
DOHOL & Doğan Holding Inc. \\
DGGYO & Doğuş Real Estate Investment Trust Inc. \\
DOAS & Doğuş Automobile Service and Trade Inc. \\
ENKAI & Enka Enka Construction and Industry Inc. \\
EREGL & Ereğli Iron and Steel Factories Inc. \\
GARFA & Garanti Factoring Inc. \\
GRNYO & Garanti Investment Trust Inc. \\
GLYHO & Global Investment Holding Inc. \\
HURGZ & Hürriyet Journalism and Typography Inc. \\
IHEVA & İhlas Household Appliances Manufacturing Industry and Trade Inc. \\
IHLAS & İhlas Holding Inc. \\
ISFIN & İs Leasing Inc. \\
ISGYO & İs Real Estate Investment Trust Inc. \\
ISMEN & İş Investment Securities Inc. \\
\hline
\end{tabular}

Source: (www.kap.org.tr)

\section{Literature Review}

Bayraktaroğlu and Çelik (2015), investigated whether corporate governance principles affect the effectiveness of the activities of the Borsa Istanbul. For this reason, the GARCH Model, which is one of the volatility models, was applied to the 1st and 2nd sessions daily values for the period between August 31, 2007 and May 27, 2014. As a result of the analysis, it was concluded that the application of Corporate Governance Principles for BIST-100 and BIST-30 Indices has a negative effect on the volatility of share returns.

Sakarya (2011) examined the relationship between the declarations of the corporate governance principles compliance rating and the share yields of the 11 companies that were listed in the BIST and were accepted to the Corporate Governance Index by obtaining valid rating for the first time in 2009. The Event Study method was preferred to determine the relationship between corporate governance principles compliance rating and stock returns. As a result of the analysis, it was concluded that there is a positive relationship between corporate governance compliance rating and stock returns. It has been revealed that abnormal returns can be provided over the share price movements before and after the announcement date of the corporate governance rating of the companies covered by the index. The author claimed that this was an indication that the market was ineffective even in semi-strong form.

Brown (2009), in his study, examined the relationship between financial performance and the corporate governance of the top 300 enterprises in Australia. He examined the relationship between the corporate governance principles practices and the financial performance of an enterprise that adopted the corporate governance principles at the Australian Stock Exchange (ASX). It has been determined that enterprises with better corporate governance practices have better financial performance than other enterprises and it is concluded that these firms have better earnings per share and asset profitability ratios.

Aksu and Aytekin (2015) examined the relationship between the Corporate Governance Principles compliance rating and the stock returns of 50 enterprises listed in BIST Corporate Governance Index (XKURY) by using the daily data between 2009-2014. Kolmogorov Smirnov test was applied by calculating the log yield averages of the shares' closing prices for the 5 and 10 days period before and after the announcement of the corporate governance rating of the enterprises. Normally distributed data were tested by paired t-test and data not normally distributed by Wilcoxon method. As a result of these analyzes, it was concluded that there was a statistically significant difference between the stock returns and the corporate governance ratings of the enterprises for before and after the announcement dates.

\section{Econometric Model and Analysis Results}

In this part of the study, data set, econometric model and explanations about the results of analysis are discussed. 


\subsection{Data Set and Model}

In order to determine the effects of the corporate governance quality on the stock prices of companies, the annual data of the 20122018 period of 27 firms, whose shares are traded in Borsa İstanbul and which are included in the Corporate Governance Index and whose corporate governance rating ratings can be reached, were used.

Corporate governance ratings are obtained from www.tkyd.org and share price information is obtained from www.investing.com.

The econometric model created in the study is as follows:

Model 1: Price $_{i t}=\beta_{0}+\beta_{1}$ Rating $_{i t}+\varepsilon_{i t}$

The description of the notations in the above equation is as follows;

Price refers to end-of-day closing prices of stocks (TL), Rating represents companies' corporate governance ratings [0-100], $\varepsilon_{-}$it expresses the series of error terms free of econometric problems. As the stock prices of the companies that has high corporate governance ratings are expected to increase, as a result of the analyzes, it is expected that the result will be $\beta_{-} 1>$ 0 .

\subsection{Method and Analysis Results}

Firstly; the existence of cross-sectional dependence between the firms included in the analysis; were tested by Breusch and Pagan (1980) LM test, Pesaran (2004) LM test, Pesaran (2004) CD test and Baltagi, Feng and Kao (2012) LMBC test. The stationary levels of the series used in the analysis were analyzed by CADF panel unit root test which was developed by Pesaran (2007) for analysis by considering the cross-sectional dependence. The coefficients in the models were estimated by the Bias Adjusted OLS (OLSAdj) method developed by Westerlund (2007) to take into account the cross-sectional dependence. The existence of causality relations between the series was investigated by Dumitrescu and Hurlin (2012) panel causality test.

\subsubsection{Horizontal Cross-Section Test}

Economic activities tend to be significantly affected from each other. Due to increasing globalization activities particularly in the 20th and 21st centuries, the possibility and speed of effect of an economic or political shock occurred in one of the countries to other countries has also increased. Particularly, a shock observed in one of the countries in close interaction or in one of the firms located in the same country can easily affect others. This is called as horizontal cross-section dependence in econometric literature. New Generation (second generation) panel data analysis methods which have been developed recently, have performed analysis by taking into consideration the possible dependence between the sections (countries, firms, etc.) that form the panel. First of all, cross-sectional dependence tests should be performed. If this type of dependency can be detected between the horizontal sections forming the panel as a result of the test, Next Generation Panel Data Analysis methods should be used.

Horizontal cross-sectional dependence tests were started with Breusch and Pagan (1980) LM tests, which were based on a standard panel data model as follows:

$$
y_{i t}=\beta_{i}^{\prime} x_{i t}+u_{i t}, \quad i=1, \ldots, N ; t=1, \ldots, T
$$

The explanations of the notations included in the model are as follows:

x_it; kx1 size of the extrinsic variables matrix,

u_it; show a series of economically error-free error terms.

Berusch and Pagan (1980), based on the Lagrange Multiplier (LM) test statistic to test the existence of a dependence between the horizontal sections.

$$
L M=T \sum_{i=1}^{N-1} \sum_{j=i+1}^{N} \hat{\rho}_{i j}^{2}
$$

Pesaran (2004), has scaled Breusch and Pagan (1980) LM test for situation where the number of horizontal cross sections is very large and he expanded Equation (3) in the following way :

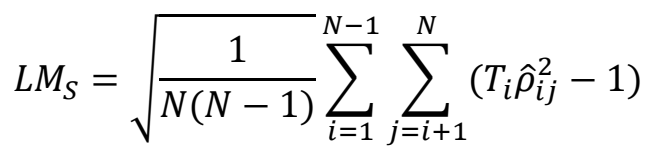




\section{Avrupa Bilim ve Teknoloji Dergisi}

Pesaran (2004) developed the CD test statistic by solving the probable size distortion problem in $L M$ and $L M_{S}$ tests:

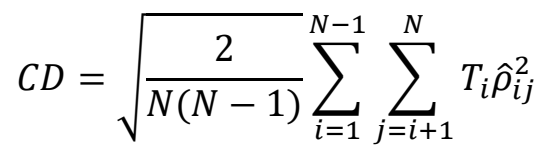

Baltagi, Feng and Kao (2012) obtained the LMBC (Bias-Corrected LM) test statistic by correcting the asymptotic deviations in the LM test:

$$
L M_{B C}=\sqrt{\frac{1}{N(N-1)} \sum_{i=1}^{N-1} \sum_{j=i+1}^{N}\left(T_{i} \hat{\rho}_{i j}^{2}-1\right)-\frac{1}{2(T-1)}}
$$

The hypotheses of these tests:

$$
\begin{aligned}
& H_{0}: \operatorname{Cov}\left(\varepsilon_{i t}, \varepsilon_{j t}\right)=0 \quad \text { There is no cross-sectional dependence in the panel. } \\
& H_{1}: \operatorname{Cov}\left(\varepsilon_{i t}, \varepsilon_{j t}\right) \neq 0 \quad \text { There is cross-sectional dependence in the panel. }
\end{aligned}
$$

2.

In this study, cross-sectional dependence tests were performed by using Eviews 10 program and the findings are presented in Table

Table 2. Horizontal Section Dependency Test Results

\begin{tabular}{|c|c|c|c|c|}
\hline & $\boldsymbol{L M}$ & $\boldsymbol{L M}$ & $\boldsymbol{C D}$ & $\boldsymbol{L M}_{\boldsymbol{B C}}$ \\
\hline Price & $\begin{array}{c}630.92 * * * \\
(0.00)\end{array}$ & $\begin{array}{c}10.56^{* * *} \\
(0.00)\end{array}$ & $\begin{array}{c}9.81^{* * *} \\
(0.00)\end{array}$ & $\begin{array}{c}8.31^{* * * *} \\
(0.00)\end{array}$ \\
\hline Rating & $\begin{array}{c}1668.28^{* * *} \\
(0.00)\end{array}$ & $\begin{array}{c}49.71^{* * *} \\
(0.00)\end{array}$ & $\begin{array}{c}40.05 * * * \\
(0.00)\end{array}$ & $\begin{array}{c}47.46^{* * *} \\
(0.00)\end{array}$ \\
\hline
\end{tabular}

Note: Numbers in parentheses refer to probability values. $* * * *$ indicates the existence of crosssectional dependence between firms in the related series at a level of $1 \%$ significance level. $L M_{B C}$ test statistics cannot be generated for models.

According to the findings in Table 2, there are cross-sectional dependence among the firms included in this study. In other words, an important economic shock in one of these companies affects the others. Then, Next Generation Panel Data Analysis methods should be taken into consideration.

\subsubsection{Panel Unit Root Test}

Stationary levels of the series used in the analysis were examined by Pesaran (2007) CADF panel unit root test, which considers the cross-sectional dependence. In this method, the test statistic required for the unit root test to be performed on a y series is shown as follows:

$$
\Delta Y_{i t}=\alpha_{i}+\beta_{i} Y_{i t-1}+\lambda_{i} f_{t}+\varepsilon_{i t}
$$

The notations in the equation are shown in the as follows:

$f_{t}$; shows common factors affecting the series. In CADF test, firstly the unit root parameters $\left(\rho_{i}\right)$ are calculated for each company, then the unit root test statistic (CIPS) that is valid for the general panel is reached.

$$
\text { CIPS }=\frac{1}{N} \sum_{i=1}^{N} \rho_{i}
$$

The hypotheses of the CADF panel unit root test are as follows:

$H_{0}: \beta_{i}=0$, The series is not stationary for all companies. 


$$
H_{1}:\left\{\begin{array}{c}
\begin{array}{c}
\text { European Journal of Science and Technology } \\
\beta_{i}<0, i=1,2, \ldots, N_{1} .
\end{array} \\
\beta_{i}=0, i=N_{1}+1, N_{1}+2, \ldots, N .
\end{array}\right.
$$

In this study, Pesaran (2007) CADF panel unit root test was performed by using Gauss 10 program and related codes written for this program and the results are presented in Table 3.

\begin{tabular}{|c|c|c|c|c|}
\hline \multirow{2}{*}{ Variables } & \multirow{2}{*}{$\begin{array}{c}\text { Calculated CIPS Test } \\
\text { Statistics }\end{array}$} & \multicolumn{3}{|c|}{ Critical Value } \\
\hline & & $\% 1$ & $\% 5$ & $\% 10$ \\
\hline Price & -11.68 & $1.85^{-}$ & $1.61^{-}$ & 1.49 \\
\hline Rating & -9.60 & $1.85^{-}$ & 1.61 & 1.49 \\
\hline
\end{tabular}

Table 3. CADF Panel Unit Root Test Results

Note: $\Delta$; shows that the first difference of the related series was taken. $* * *, * *$ and $* ; 1$ indicate related series are stationary in the significance level $\%, 5 \%$ and $10 \%$ respectively. Critical values are those obtained from Table II (a) of Pesaran (2007: 279) and valid for $\mathrm{T}=10, \mathrm{~N}=30$.

According to the results in Table 3, series are stationary in their original values in other words they are (I). In this case, analysis which will be based on original values of the series will not face false regression problem and the results will be reliable. As the series is stationary at the original level values, there is no need to perform panel cointegration testing.

\subsubsection{Panel Regression Analysis}

The coefficients in the models were estimated by using the Bias Adjusted OLS Estimator: OLSAdj method developed by Westerlund (2007) by correcting the deviation of Bai-Kao (2006) Cup-Fm method. This method considers the cross-sectional dependence through common factors in the series and takes into account the intrinsicity. It is a robust estimation method for autocorrelation and heteroscedasticity problems.

In the study, the coefficients in the models were calculated by using Westerlund (2007) OLSAdj method with Gauss 10 program and codes written for this program and the results obtained are presented in Table 4.

Table 4. Panel Regression Analysis Results

\begin{tabular}{|l|c|c|}
\hline & Rating & Constant Item \\
\hline Model 1 & $1.13[12.69]$ & $0.91[6.35]$ \\
\hline
\end{tabular}

Note: Values included in the [ ] are t statistics. The t statistic table values in the $10 \%, 5 \%$ and $1 \%$ significance levels are respectively; $1.28,1.64$ and 2.32 .

According to the findings in Table 4, when the corporate governance quality of the companies increases by 1 unit, stock prices will increase by TL 1.13 . These results are very useful in terms of revealing the importance of corporate governance quality in increasing stock prices. It is useful for the top managers of the firms to focus on this issue. The signs of the coefficients obtained are consistent with our expectations.

\subsubsection{Panel Causality Test}

In this study, the existence of causality relations between the series was examined by the method developed by Dumitrescu and Hurlin (2012). This method can also consider the cross-sectional dependence between the horizontal cross-sections (firms in this study) and the causality relationships between some horizontal cross-sections. This test is based on the following models

$$
\begin{aligned}
& y_{i t}=\alpha_{i}+\sum_{k=1}^{K} \gamma_{i}^{(k)} y_{i t-k}+\sum_{k=1}^{K} \beta_{i}^{(k)} x_{i t-k}+\varepsilon_{i, t} \\
& x_{i t}=\theta_{i}+\sum_{k=1}^{K} \varphi_{i}^{(k)} x_{i t-k}+\sum_{k=1}^{K} \psi_{i}^{(k)} y_{i t-k}+\epsilon_{i, t}
\end{aligned}
$$


Test hypotheses:

$H_{0}: \beta_{i}=0$, There is no causality from $x$ to $y$ in all horizontal sections

$H_{1}:\left\{\begin{array}{c}\beta_{i}<0, i=1,2, \ldots, N_{1} . \quad \text { There is causal relationship from } x \text { to } y \text { in some horizontal sections. } \\ \beta_{i}=0, i=N_{1}+1, N_{1}+2, \ldots, N \text {. There is no causality from } x \text { to } y \text { in some horizontal sections. }\end{array}\right.$

Dumitrescu and Hurlin (2012) developed two different test statistics to test this hypothesis:

$$
\begin{aligned}
& W=\frac{1}{N} \sum_{i=1}^{N} W_{i, T} \\
& Z=\sqrt{\frac{N}{2 K}}(W-K)
\end{aligned}
$$

Here $W_{i T}$; shows individual Wald statistics. $K$ is the expected value of $W_{i T}$; Dumitrescu and Hurlin (2012) panel causality test was conducted by Eviews 10 program and the findings are presented in Table 5.

Table 5. Panel Causality Test Results

\begin{tabular}{|c|c|c|c|}
\hline Null Hypothesis & W Statistic & $\bar{Z}$ Statistic & $\begin{array}{c}\text { Probability } \\
\text { Value }\end{array}$ \\
\hline Rating $\nrightarrow$ Price & 3.35 & 1.25 & $0.03^{* *}$ \\
\hline Price $\rightarrow$ Rating & 1.11 & 0.25 & 0.32 \\
\hline
\end{tabular}

Note: $* * *, * *$ and $*$ indicate that there is a causality relationship from the first variable to the second variable at the level of $1 \%, 5 \%$ and $10 \%$ respectively.

According to the findings in Table 5, one-way causality relationships were determined from the corporate governance quality (Note) to stock prices. These results are important for reinforcing the effects of corporate governance quality on stock prices These results provides important information for the company managers trying to keep their stock prices high or ensure their price stability. It can be concluded that managers firstly improve their corporate governance quality.

\section{Conclusion and Recommendation}

In this study, the effects of corporate governance ratings of companies listed in Borsa İstanbul's Corporate Governance Index on share price performance are examined. For this purpose, the annual data of the 27 companies which are included in the index and whose data can be reached are used in the analysis. The econometric model which was established in this study was investigated through the New Generation Panel Data Analysis methods. Due to the possibility of convergence of firms, the existence of cross-sectional dependence among the firms included in the analysis was investigated. Breusch and Pagan (1980) LM test, Pesaran (2004) LM test, Pesaran (2004) CD test and Baltagi, Feng and Kao (2012) LMBC test were performed for horizontal cross-sectional dependence and it was found that there was horizontal cross-sectional dependence between firms. As a result, it was decided that the Next Generation Panel Data Analysis methods considering the cross - sectional cross - sectional dependence should be used in the later stages of the study.

In the next stage of the analysis, stationary levels of the series were testes by unit root test. Due to the cross-sectional dependence was found between the sections, in the model Pesaran (2007) CADF panel unit root test that considers the horizontal dependence was used. As a result of the test, it was determined that all series were stationary in other words they are $\mathrm{I}(0)$. Therefore, the models created through these series will not have a spurious regression problem in other words, the results will be reliable. As the series is stationary at the original level values, there is no need to perform panel cointegration testing. The coefficients in the models were estimated by using the Bias Adjusted OLS Estimator (OLSAdj) method developed by Westerlund (2007) by correcting the deviation of Bai-Kao (2006) Cup-Fm method. According to these estimations, when the corporate governance quality of the companies increases by 1 unit, the share price will increase by TL 1.13 . These results reveal the importance of the quality of corporate governance practices in increasing the firm values of companies and making them sustainable. The firm needs to pay attention to the importance of corporate governance practices in order to increase the reputation of the firms in the eyes of the existing and potential investors, to make the stability of stock prices sustainable and to reduce the cost of capital. 
European Journal of Science and Technology

The existence of causality relations between the series included in the model was examined by the method developed by Dumitrescu and Hurlin (2012). According to the results of the test, the one-way causality relationship of the companies from the corporate governance rating to the stock prices was observed. This result is important in terms of showing the effects of corporate governance quality on stock prices once more again.

As a result, it has been determined that it is possible to have a high and sustainable market value thanks to the reputation and brand value provided by the companies to comply with the corporate governance practices. Firm management should regard corporate governance activities as a strategic investment tool rather than a cost element.

\section{References}

Acungüç, A. Ç. (2017). Kurumsal Yönetim Uygulamalarının Hisse Senetleri Borsada Işslem Gören Şirketler Üzerindeki Etkisi ve Değerlendirilmesi. İstanbul: T.C. Okan Üniversitesi Sosyal Bilimler Enstitüsü

Aksu, M., Aytekin,S. (2015), Kurumsal Yönetim İlkelerine Uyum Notu İle Hisse Senedi Getirisi İlişkisi: BIST Kurumsal Yönetim Endeksi (XKURY) Üzerine Bir Uygulama, Gümüşhane Üniversitesi Sosyal Bilimler Elektronik Dergisi, Say1:13, Cilt:6, S: 2012019, DOI: 10.17823/gusb.193

Bai, J. and Kao, C. (2006). On the Estimation and Inference of a Panel Cointegration Model with Cross Sectional Dependence. in Badi Baltagi (Ed.), Panel Data Econometrics: Theoretical Contributions and Empirical Applications, Amsterdam: Elsevier Science, pp. 3- 30.

Baltagi, B. H, Feng, Q. and C. Kao (2012). A Lagrange Multiplier test for Cross-sectional Dependence in a Fixed Effects Panel Data Model. Journal of the Econometrics, 170, 164-177.

Bayraktaroğlu, H. ve Çelik, İ. (2015), Kurumsal Yönetim Uygulamalarının Getiri Oynaklığı Üzerine Etkisi: Borsa İstanbul'da Bir Araştırma, Akdeniz Üniversitesi İIBF Dergisi, Cilt XVII Sayı:1,S: 97-108

Breusch, T.S and Pagan, A.R. (1980). The Lagrange Multiplier Test and Its Applications to Model Econometrics. Review of Economic Studies, 47, 239-53.

Brown,R.(2009), Treasury Working Paper, http://archive.treasury.gov.au/documents/ 1495/PDF/ TWP 2009-02.pdf

Demirbaş, M., Uyar, S. (2006). Kurumsal Yönetim İlkeleri ve Denetim Komitesi. İstanbul : Güncel Yayınc1lık.

Dumitrescu, E.I. and Hurlin, C. (2012). Testing for Granger Non-Causality in Heterogeneous Panels. Economic Modelling, 29(4), 1450-1460.

Eberhardt, M. and Bond, S. (2009). Cross-section Dependence in Nonstationary Panel Models: A Novel Estimator. MPRA Paper, No. 17870.

Ertuna, B., ve Tükel, A. (2008), Şirketlerin Kamuyu Aydınlatma Düzeyleri: Ortaklık Yapısı Ve Kurumsal Yönetimin Etkileri, İ.M.K.B. Dergisi, Say1:40.

Pesaran, M.H. (2004). General Diagnostic Tests for Cross Section Dependence in Panels, Cambridge Working Papers in Economics, 435.

Sakarya, Ş. (2011), İMKB Kurumsal Yönetim Endeksi Kapsamındaki Şirketlerin Kurumsal Yönetim Derecelendirme Notu ve Hisse Senedi Getirileri Arasındaki İlişkinin Olay Çalışması (Event Study) Yöntemi İle Analizi, Zonguldak Karaelmas Üniversitesi Sosyal Bilimler Dergisi, Cilt:7, Say1:13, S: 147-162

TKYD ve Delolitte . (2006). Nedir Bu Kurumsal Yönetim? İstanbul: TKYD ve Deloitte Ortak Yayını.

Westerlund, J. (2007). Estimating Cointegrated Panels with Common Factors and the Forward Rate Unbiasedness Hypothesis. Journal of Financial 
Appendix:

Annex 1. Annual stock returns and corporate governance ratings of the firms included in the sample

\begin{tabular}{|c|c|c|c|c|c|c|}
\hline Equity Code & Year & Rating & Stock Price Performance & Stocks Closing Price & $\begin{array}{c}\text { Operating Profi \& Loss - } \\
\%\end{array}$ & Operating Profit \& Loss \\
\hline AEFES & 2012 & 89,39 & $14,98 \%$ & 23,79 & $-10,58 \%$ & 540.206 .000 \\
\hline AEFES & 2013 & 93,30 & $-7,99 \%$ & 21,89 & $36,40 \%$ & 736.820 .000 \\
\hline AEFES & 2014 & 91,26 & $-2,38 \%$ & 21,37 & $24,28 \%$ & 915.707 .000 \\
\hline AEFES & 2015 & 95,46 & $-15,16 \%$ & 18,13 & $8,47 \%$ & 993.310 .000 \\
\hline AEFES & 2016 & 95,77 & $-28,01 \%$ & 17,14 & $-5,37 \%$ & 939.940 .000 \\
\hline AEFES & 2017 & 95,77 & $31,33 \%$ & 23,81 & $33,19 \%$ & 1.251 .949 .000 \\
\hline AEFES & 2018 & 95,83 & $20,19 \%$ & 20,60 & $28,28 \%$ & 1.605 .960 .000 \\
\hline AGHOL & 2012 & 87,75 & $63,13 \%$ & 14,91 & $-67,12 \%$ & 76.528 .000 \\
\hline AGHOL & 2013 & 90,73 & $18,98 \%$ & 17,74 & $-21,45 \%$ & 60.111 .000 \\
\hline AGHOL & 2014 & 88,16 & $4,90 \%$ & 18,61 & $55,23 \%$ & 93.308 .000 \\
\hline AGHOL & 2015 & 91,69 & $-34,01 \%$ & 12,28 & $58,69 \%$ & 148.067 .000 \\
\hline AGHOL & 2016 & 91,88 & $3,66 \%$ & 12,73 & $596,02 \%$ & 1.030 .574 .000 \\
\hline AGHOL & 2017 & 92,01 & $85,31 \%$ & 23,59 & $42,11 \%$ & 1.464 .508 .000 \\
\hline AGHOL & 2018 & 95,28 & $-56,59 \%$ & 10,24 & $30,51 \%$ & 1.911 .378 .000 \\
\hline ALBRK & 2012 & 82,20 & $81,48 \%$ & 1,47 & $19,32 \%$ & 241.225 .000 \\
\hline ALBRK & 2013 & 86,16 & $-9,52 \%$ & 1,33 & $24,18 \%$ & 299.543 .000 \\
\hline ALBRK & 2014 & 83,92 & $15,04 \%$ & 1,53 & $8,68 \%$ & 325.552 .000 \\
\hline ALBRK & 2015 & 85,86 & $-22,22 \%$ & 1,19 & $15,74 \%$ & 376.778 .000 \\
\hline ALBRK & 2016 & 87,54 & $-6,72 \%$ & 1,11 & $-29,95 \%$ & 263.920 .000 \\
\hline ALBRK & 2017 & 88,05 & $35,14 \%$ & 1,50 & $9,43 \%$ & 288.800 .000 \\
\hline ALBRK & 2018 & 89,23 & $-18,67 \%$ & 1,22 & $-41,66 \%$ & 168.495 .000 \\
\hline ARCLK & 2012 & 91,07 & $102,11 \%$ & 9,60 & $15,97 \%$ & 763.700 .000 \\
\hline ARCLK & 2013 & 92,80 & $8,13 \%$ & 10,38 & $12,76 \%$ & 861.147 .000 \\
\hline ARCLK & 2014 & 91,00 & $28,32 \%$ & 13,32 & $14,70 \%$ & 987.741 .000 \\
\hline ARCLK & 2015 & 94,80 & $-3,60 \%$ & 12,84 & $10,01 \%$ & 1.086 .638 .000 \\
\hline ARCLK & 2016 & 95,23 & $54,91 \%$ & 19,89 & $10,23 \%$ & 1.197 .777 .000 \\
\hline ARCLK & 2017 & 95,23 & $4,42 \%$ & 20,77 & $14,52 \%$ & 1.371 .744 .000 \\
\hline ARCLK & 2018 & 95,35 & $-23,98 \%$ & 15,79 & $48,50 \%$ & 2.037 .064 .000 \\
\hline AYGAZ & 2012 & 89,57 & $12,95 \%$ & 5,06 & $12,39 \%$ & 167.253 .000 \\
\hline AYGAZ & 2013 & 92,71 & $-4,35 \%$ & 4,84 & $2,56 \%$ & 171.529 .000 \\
\hline AYGAZ & 2014 & 91,35 & $28,10 \%$ & 6,20 & $-31,07 \%$ & 118.235 .000 \\
\hline AYGAZ & 2015 & 93,58 & $6,29 \%$ & 6,59 & $114,61 \%$ & 253.739 .000 \\
\hline AYGAZ & 2016 & 93,61 & $30,05 \%$ & 8,57 & $22,56 \%$ & 310.980 .000 \\
\hline AYGAZ & 2017 & 93,64 & $48,42 \%$ & 12,72 & $-20,42 \%$ & 247.481 .000 \\
\hline AYGAZ & 2018 & 93,99 & $-21,86 \%$ & 9,94 & $-52,12 \%$ & 118.497 .000 \\
\hline CCOLA & 2012 & 88,81 & $65,27 \%$ & 35,17 & $42,87 \%$ & 461.412 .000 \\
\hline CCOLA & 2013 & 92,01 & $40,60 \%$ & 49,45 & $29,01 \%$ & 595.284 .000 \\
\hline CCOLA & 2014 & 90,17 & $-1,80 \%$ & 48,56 & $6,84 \%$ & 635.991 .000 \\
\hline CCOLA & 2015 & 94,02 & $-25,80 \%$ & 36,03 & $5,11 \%$ & 668.460 .000 \\
\hline CCOLA & 2016 & 94,48 & $-10,57 \%$ & 32,22 & $-5,91 \%$ & 628.955 .000 \\
\hline CCOLA & 2017 & 94,52 & $3,94 \%$ & 33,49 & $36,62 \%$ & 859.259 .000 \\
\hline CCOLA & 2018 & 94,52 & $-7,79 \%$ & 30,88 & $41,48 \%$ & 1.215 .683 .000 \\
\hline DOAS & 2012 & 82,15 & $222,49 \%$ & 5,45 & $20,02 \%$ & 303.678 .000 \\
\hline DOAS & 2013 & 90,05 & $-15,05 \%$ & 4,63 & $-9,14 \%$ & 275.912 .000 \\
\hline DOAS & 2014 & 91,45 & $101,73 \%$ & 9,34 & $15,51 \%$ & 318.697 .000 \\
\hline DOAS & 2015 & 94,20 & $-3,53 \%$ & 9,01 & $36,43 \%$ & 434.794 .000 \\
\hline DOAS & 2016 & 95,10 & $-10,88 \%$ & 8,03 & $-21,20 \%$ & 342.611 .000 \\
\hline DOAS & 2017 & 96,30 & $-6,10 \%$ & 7,54 & $32,20 \%$ & 452.937 .000 \\
\hline DOAS & 2018 & 96,41 & $-42,44 \%$ & 4,34 & $12,33 \%$ & 508.773 .000 \\
\hline DOHOL & 2012 & 90,31 & $73,47 \%$ & 0,85 & $407,86 \%$ & 123.553 .000 \\
\hline DOHOL & 2013 & 91,81 & $-21,18 \%$ & 0,67 & $-88,57 \%$ & 14.122 .000 \\
\hline DOHOL & 2014 & 90,00 & $2,99 \%$ & 0,69 & $-586,11 \%$ & 68.648 .000 \\
\hline DOHOL & 2015 & 93,56 & $-24,64 \%$ & 0,52 & $-227,77 \%$ & 87.714 .000 \\
\hline DOHOL & 2016 & 93,98 & $32,69 \%$ & 0,69 & $124,84 \%$ & 197.217 .000 \\
\hline DOHOL & 2017 & 94,06 & $14,49 \%$ & 0,79 & $-106,08 \%$ & 11.984 .000 \\
\hline DOHOL & 2018 & 94,18 & $17,72 \%$ & 0,93 & $-3208,94 \%$ & 372.575 .000 \\
\hline GLYHO & 2012 & 88,04 & $13,51 \%$ & 1,26 & $-99,32 \%$ & 141.478 \\
\hline GLYHO & 2013 & 88,60 & $-0,79 \%$ & 1,25 & $-629,69 \%$ & 749.388 \\
\hline GLYHO & 2014 & 88,60 & $9,60 \%$ & 1,37 & $-2088,38 \%$ & 14.900 .652 \\
\hline GLYHO & 2015 & 87,92 & $20,44 \%$ & 1,65 & $-271,48 \%$ & 25.551 .249 \\
\hline GLYHO & 2016 & 89,90 & $-2,42 \%$ & 1,61 & $24,82 \%$ & 31.892 .471 \\
\hline GLYHO & 2017 & 90,52 & $124,22 \%$ & 3,61 & $-99,24 \%$ & 242.465 \\
\hline
\end{tabular}


European Journal of Science and Technology

\begin{tabular}{|c|c|c|c|c|c|c|}
\hline Equity Code & Year & Rating & Stock Price Performance & Stocks Closing Price & Operating Profi \& Loss - & Operating Profit \& Loss \\
\hline GLYHO & 2018 & 90,60 & $-17,17 \%$ & 2,99 & $51034,68 \%$ & 123.983 .710 \\
\hline HALKB & 2012 & 87,73 & $80,57 \%$ & 15,71 & $26,26 \%$ & 3.329 .139 .000 \\
\hline HALKB & 2013 & 92,05 & $-29,15 \%$ & 11,13 & $1,07 \%$ & 3.364 .892 .000 \\
\hline HALKB & 2014 & 89,58 & $16,26 \%$ & 12,94 & $-18,95 \%$ & 2.727 .255 .000 \\
\hline HALKB & 2015 & 92,63 & $-24,27 \%$ & 9,80 & $4,71 \%$ & 2.855 .643 .000 \\
\hline HALKB & 2016 & 92,97 & $-8,47 \%$ & 8,97 & $17,37 \%$ & 3.351 .550 .000 \\
\hline HALKB & 2017 & 93,76 & $17,28 \%$ & 10,52 & $40,52 \%$ & 4.709.582.000 \\
\hline HALKB & 2018 & 93,96 & $-33,27 \%$ & 7,02 & $-42,29 \%$ & 2.717 .818 .000 \\
\hline HURGZ & 2012 & 90,90 & $31,43 \%$ & 0,92 & $314,60 \%$ & 25.467 .874 \\
\hline HURGZ & 2013 & 90,90 & $-34,78 \%$ & 0,60 & $-93,95 \%$ & 1.540 .966 \\
\hline HURGZ & 2014 & 90,83 & $43,33 \%$ & 0,86 & $-1854,62 \%$ & 27.038 .052 \\
\hline HURGZ & 2015 & 93,58 & $-30,23 \%$ & 0,60 & $-104,81 \%$ & 1.300 .772 \\
\hline HURGZ & 2016 & 92,79 & $23,33 \%$ & 0,74 & $1415,63 \%$ & 19.714 .887 \\
\hline HURGZ & 2017 & 91,27 & $81,08 \%$ & 1,34 & $-0,56 \%$ & 19.603 .696 \\
\hline HURGZ & 2018 & 92,67 & $-30,60 \%$ & 0,93 & $-329,12 \%$ & 44.916 .670 \\
\hline IHEVA & 2012 & 76,75 & $19,35 \%$ & 0,74 & $-75,12 \%$ & 1.585 .534 \\
\hline IHEVA & 2013 & 80,49 & $-44,59 \%$ & 0,41 & $-298,69 \%$ & 3.150 .239 \\
\hline IHEVA & 2014 & 77,93 & $-12,20 \%$ & 0,36 & $-182,73 \%$ & 2.606 .183 \\
\hline IHEVA & 2015 & 80,60 & $-16,67 \%$ & 0,30 & $-356,09 \%$ & 6.674 .131 \\
\hline IHEVA & 2016 & 80,82 & $-3,33 \%$ & 0,29 & $22,91 \%$ & 8.202 .950 \\
\hline IHEVA & 2017 & 81,99 & $75,86 \%$ & 0,51 & $60,70 \%$ & 13.182 .501 \\
\hline IHEVA & 2018 & 83,75 & $-35,29 \%$ & 0,33 & $109,59 \%$ & 27.628 .779 \\
\hline IHLAS & 2012 & 80,94 & $62,34 \%$ & 1,25 & $-64,16 \%$ & 16.465 .413 \\
\hline IHLAS & 2013 & 81,48 & $-66,40 \%$ & 0,42 & $358,15 \%$ & 75.435 .527 \\
\hline IHLAS & 2014 & 78,57 & $-26,19 \%$ & 0,31 & $20,30 \%$ & 90.745 .879 \\
\hline IHLAS & 2015 & 80,38 & $-29,03 \%$ & 0,22 & $17,40 \%$ & 106.531 .284 \\
\hline IHLAS & 2016 & 80,46 & $36,36 \%$ & 0,30 & $-182,21 \%$ & 87.578 .135 \\
\hline IHLAS & 2017 & 81,45 & $76,67 \%$ & 0,53 & $-86,04 \%$ & 12.223 .756 \\
\hline IHLAS & 2018 & 83,32 & $6,67 \%$ & 0,32 & $677,23 \%$ & 95.006 .115 \\
\hline LOGO & 2012 & 85,97 & $158,99 \%$ & 3,60 & $80,12 \%$ & 11.949 .689 \\
\hline LOGO & 2013 & 89,12 & $22,22 \%$ & 4,40 & $74,70 \%$ & 20.876 .694 \\
\hline LOGO & 2014 & 85,47 & $519,09 \%$ & 27,24 & $41,61 \%$ & 29.563 .687 \\
\hline LOGO & 2015 & 90,76 & $57,12 \%$ & 42,80 & $36,86 \%$ & 40.459 .639 \\
\hline LOGO & 2016 & 91,24 & $26,99 \%$ & 54,35 & $70,58 \%$ & 69.014 .638 \\
\hline LOGO & 2017 & 90,83 & $8,10 \%$ & 58,75 & $-14,97 \%$ & 58.681 .661 \\
\hline LOGO & 2018 & 91,14 & $-53,80 \%$ & 27,14 & $16,25 \%$ & 68.219 .374 \\
\hline OTKAR & 2012 & 86,80 & $83,59 \%$ & 32,66 & $25,42 \%$ & 94.029 .871 \\
\hline OTKAR & 2013 & 91,03 & $36,22 \%$ & 44,49 & $40,41 \%$ & 132.028 .553 \\
\hline OTKAR & 2014 & 89,22 & $70,29 \%$ & 75,76 & $-15,83 \%$ & 111.133 .109 \\
\hline OTKAR & 2015 & 92,81 & $7,19 \%$ & 81,21 & $-4,16 \%$ & 106.508 .909 \\
\hline OTKAR & 2016 & 93,19 & $52,69 \%$ & 124,00 & $13,63 \%$ & 121.024 .000 \\
\hline OTKAR & 2017 & 93,32 & $-5,26 \%$ & 117,48 & $2,29 \%$ & 123.796 .000 \\
\hline OTKAR & 2018 & 91,03 & $-26,89 \%$ & 85,89 & $33,72 \%$ & 165.537 .000 \\
\hline PNSUT & 2012 & 88,67 & $12,51 \%$ & 10,43 & $-22,48 \%$ & 53.027 .836 \\
\hline PNSUT & 2013 & 91,49 & $15,82 \%$ & 12,08 & $2,76 \%$ & 54.491 .224 \\
\hline PNSUT & 2014 & 88,63 & $28,48 \%$ & 15,52 & $-0,73 \%$ & 54.093 .421 \\
\hline PNSUT & 2015 & 91,78 & $-14,43 \%$ & 13,28 & $-0,28 \%$ & 53.943 .908 \\
\hline PNSUT & 2016 & 92,37 & $2,11 \%$ & 13,56 & $20,60 \%$ & 65.058 .187 \\
\hline PNSUT & 2017 & 92,62 & $-16,08 \%$ & 11,38 & $-13,91 \%$ & 56.007 .432 \\
\hline PNSUT & 2018 & 92,71 & $-45,34 \%$ & 6,22 & $37,20 \%$ & 76.839 .544 \\
\hline PRKAB & 2012 & 84,39 & $-1,87 \%$ & 1,05 & $22,48 \%$ & 13.569 .917 \\
\hline PRKAB & 2013 & 86,55 & $18,10 \%$ & 1,24 & $3,99 \%$ & 14.111 .181 \\
\hline PRKAB & 2014 & 86,59 & $2,42 \%$ & 1,27 & $125,39 \%$ & 31.805 .175 \\
\hline PRKAB & 2015 & 90,90 & $89,76 \%$ & 2,41 & $21,16 \%$ & 38.535 .332 \\
\hline PRKAB & 2016 & 90,92 & $-19,09 \%$ & 1,95 & $-7,93 \%$ & 35.479 .358 \\
\hline PRKAB & 2017 & 91,13 & $25,64 \%$ & 2,45 & $-42,35 \%$ & 20.454 .024 \\
\hline PRKAB & 2018 & 91,76 & $-29,80 \%$ & 1,72 & $237,10 \%$ & 68.949 .927 \\
\hline PRKME & 2012 & 88,24 & $102,55 \%$ & 3,97 & $26,22 \%$ & 101.693 .610 \\
\hline PRKME & 2013 & 89,80 & $-19,90 \%$ & 3,18 & $-66,34 \%$ & 34.228 .853 \\
\hline PRKME & 2014 & 86,96 & $-10,06 \%$ & 2,86 & $-151,25 \%$ & 17.543 .742 \\
\hline PRKME & 2015 & 90,29 & $-12,59 \%$ & 2,50 & $-100,08 \%$ & 13.583 \\
\hline PRKME & 2016 & 90,79 & $-18,40 \%$ & 2,04 & $-121531,21 \%$ & 16.494 .001 \\
\hline PRKME & 2017 & 90,79 & $104,41 \%$ & 4,17 & $-7,96 \%$ & 15.180 .984 \\
\hline PRKME & 2018 & 90,01 & $-42,21 \%$ & 2,41 & $-23,10 \%$ & 11.674 .523 \\
\hline SKBNK & 2012 & 88,21 & $98,77 \%$ & 1,61 & $97,19 \%$ & 310.685 .000 \\
\hline
\end{tabular}


Avrupa Bilim ve Teknoloji Dergisi

\begin{tabular}{|c|c|c|c|c|c|c|}
\hline Equity Code & Year & Rating & Stock Price Performance & Stocks Closing Price & Operating Profi \& Loss - & Operating Profit \& Loss \\
\hline SKBNK & 2013 & 90,95 & $16,15 \%$ & 1,87 & $-14,92 \%$ & 264.339 .000 \\
\hline SKBNK & 2014 & 90,83 & $-5,88 \%$ & 1,76 & $6,19 \%$ & 280.701 .000 \\
\hline SKBNK & 2015 & 91,10 & $-4,55 \%$ & 1,68 & $-69,63 \%$ & 85.246 .000 \\
\hline SKBNK & 2016 & 91,70 & $-29,76 \%$ & 1,18 & $63,78 \%$ & 139.615 .000 \\
\hline SKBNK & 2017 & 91,90 & $55,08 \%$ & 1,83 & $-0,06 \%$ & 139.527 .000 \\
\hline SKBNK & 2018 & 92,70 & $-6,78 \%$ & 1,10 & $-24,88 \%$ & 104.813 .000 \\
\hline TAVHL & 2012 & 92,44 & $16,19 \%$ & 6,53 & $27,06 \%$ & 362.576 .000 \\
\hline TAVHL & 2013 & 93,97 & $75,19 \%$ & 11,44 & $32,85 \%$ & 481.668 .000 \\
\hline TAVHL & 2014 & 92,96 & $27,88 \%$ & 14,63 & $29,05 \%$ & 621.614 .000 \\
\hline TAVHL & 2015 & 95,19 & $-1,30 \%$ & 14,44 & $38,89 \%$ & 863.337 .000 \\
\hline TAVHL & 2016 & 95,38 & $-18,42 \%$ & 11,78 & $22,17 \%$ & 1.054 .706 .000 \\
\hline TAVHL & 2017 & 96,17 & $67,49 \%$ & 19,73 & $32,54 \%$ & 1.397 .886 .000 \\
\hline TAVHL & 2018 & 96,25 & $11,45 \%$ & 21,99 & $65,68 \%$ & 2.316 .012 .000 \\
\hline TOASO & 2012 & 90,25 & $88,44 \%$ & 7,01 & $-2,28 \%$ & 479.906 .000 \\
\hline TOASO & 2013 & 91,39 & $39,37 \%$ & 9,77 & $1,51 \%$ & 487.151 .000 \\
\hline TOASO & 2014 & 87,93 & $25,38 \%$ & 12,25 & $9,55 \%$ & 533.669 .000 \\
\hline TOASO & 2015 & 90,61 & $26,12 \%$ & 15,45 & $32,86 \%$ & 709.009 .000 \\
\hline TOASO & 2016 & 91,38 & $34,50 \%$ & 20,78 & $19,02 \%$ & 843.896 .000 \\
\hline TOASO & 2017 & 91,48 & $37,58 \%$ & 28,59 & $54,61 \%$ & 1.304 .776 .000 \\
\hline TOASO & 2018 & 92,04 & $-45,75 \%$ & 15,51 & $34,70 \%$ & 1.757 .524 .000 \\
\hline TRCAS & 2012 & 84,00 & $48,84 \%$ & 2,56 & $17,19 \%$ & 12.194 .636 \\
\hline TRCAS & 2013 & 87,51 & $-22,66 \%$ & 1,98 & $7,25 \%$ & 13.078 .321 \\
\hline TRCAS & 2014 & 90,90 & $2,53 \%$ & 2,03 & $10,99 \%$ & 14.515 .823 \\
\hline TRCAS & 2015 & 92,70 & $-27,09 \%$ & 1,48 & $44,34 \%$ & 20.951 .641 \\
\hline TRCAS & 2016 & 93,50 & $2,03 \%$ & 1,51 & $6,99 \%$ & 22.416 .235 \\
\hline TRCAS & 2017 & 94,86 & $66,23 \%$ & 2,51 & $16,28 \%$ & 26.064 .679 \\
\hline TRCAS & 2018 & 95,70 & $-43,82 \%$ & 1,41 & $-123,11 \%$ & 6.023 .433 \\
\hline TTKOM & 2012 & 88,01 & $6,65 \%$ & 5,45 & $-4,08 \%$ & 3.246 .331 .000 \\
\hline TTKOM & 2013 & 88,02 & $-6,24 \%$ & 5,11 & $-7,14 \%$ & 3.014 .653 .000 \\
\hline TTKOM & 2014 & 85,20 & $27,20 \%$ & 6,50 & $-6,20 \%$ & 2.827 .749 .000 \\
\hline TTKOM & 2015 & 89,08 & $-19,23 \%$ & 5,25 & $1,34 \%$ & 2.865 .599 .000 \\
\hline TTKOM & 2016 & 90,24 & $0,57 \%$ & 5,28 & $-9,56 \%$ & 2.591 .752 .000 \\
\hline TTKOM & 2017 & 91,75 & $21,97 \%$ & 6,44 & $49,49 \%$ & 3.874 .312 .000 \\
\hline TTKOM & 2018 & 92,87 & $-39,44 \%$ & 3,90 & $24,91 \%$ & 4.839 .350 .000 \\
\hline TTRAK & 2012 & 89,02 & $91,99 \%$ & 37,61 & $-5,42 \%$ & 294.203 .542 \\
\hline TTRAK & 2013 & 91,04 & $12,50 \%$ & 42,31 & $10,49 \%$ & 325.058 .490 \\
\hline TTRAK & 2014 & 88,86 & $37,79 \%$ & 58,30 & $-8,71 \%$ & 296.742 .363 \\
\hline TTRAK & 2015 & 90,85 & $-2,68 \%$ & 56,74 & $22,62 \%$ & 363.867 .627 \\
\hline TTRAK & 2016 & 91,49 & $15,56 \%$ & 65,57 & $25,00 \%$ & 454.817 .128 \\
\hline TTRAK & 2017 & 92,13 & $7,50 \%$ & 70,49 & $-6,90 \%$ & 423.428 .607 \\
\hline TTRAK & 2018 & 92,16 & $-50,49 \%$ & 34,90 & $-2,95 \%$ & 410.918 .822 \\
\hline TUPRS & 2012 & 91,00 & $41,11 \%$ & 31,27 & $-46,30 \%$ & 1.024 .982 .000 \\
\hline TUPRS & 2013 & 93,43 & $-10,33 \%$ & 28,04 & $-24,53 \%$ & 773.582 .000 \\
\hline TUPRS & 2014 & 89,91 & $33,59 \%$ & 37,46 & $-31,36 \%$ & 530.996 .000 \\
\hline TUPRS & 2015 & 94,41 & $25,87 \%$ & 47,15 & $511,93 \%$ & 3.249 .302 .000 \\
\hline TUPRS & 2016 & 94,15 & $10,80 \%$ & 52,24 & $-18,33 \%$ & 2.653 .780 .000 \\
\hline TUPRS & 2017 & 94,67 & $84,59 \%$ & 96,43 & $90,81 \%$ & 5.063 .658 .000 \\
\hline TUPRS & 2018 & 94,81 & $8,20 \%$ & 104,34 & $56,35 \%$ & 7.916 .939 .000 \\
\hline VESTL & 2012 & 88,32 & $4,42 \%$ & 1,89 & $-116,66 \%$ & 73.002 .000 \\
\hline VESTL & 2013 & 90,94 & $-17,99 \%$ & 1,55 & $-313,36 \%$ & 155.757 .000 \\
\hline VESTL & 2014 & 89,92 & $309,68 \%$ & 6,35 & $191,18 \%$ & 453.535 .000 \\
\hline VESTL & 2015 & 91,24 & $-19,53 \%$ & 5,11 & $28,89 \%$ & 584.572 .000 \\
\hline VESTL & 2016 & 93,60 & $24,27 \%$ & 6,35 & $-4,07 \%$ & 560.800 .000 \\
\hline VESTL & 2017 & 94,86 & $19,21 \%$ & 7,57 & $-10,82 \%$ & 500.111 .000 \\
\hline VESTL & 2018 & 96,50 & $-26,68 \%$ & 5,55 & $268,96 \%$ & 1.845 .202 .000 \\
\hline YKBNK & 2012 & 88,08 & $92,68 \%$ & 3,16 & $4,00 \%$ & 2.449 .242 .000 \\
\hline YKBNK & 2013 & 93,22 & $-27,53 \%$ & 2,29 & $4,37 \%$ & 2.556 .327 .000 \\
\hline YKBNK & 2014 & 90,34 & $34,50 \%$ & 3,08 & $-14,02 \%$ & 2.197 .965 .000 \\
\hline YKBNK & 2015 & 93,35 & $-31,17 \%$ & 2,12 & $-8,04 \%$ & 2.021 .348 .000 \\
\hline YKBNK & 2016 & 93,42 & $4,25 \%$ & 2,21 & $56,74 \%$ & 3.168 .213 .000 \\
\hline YKBNK & 2017 & 94,29 & $26,70 \%$ & 2,80 & $23,05 \%$ & 3.898 .596 .000 \\
\hline YKBNK & 2018 & 95,75 & $-42,86 \%$ & 1,60 & $30,30 \%$ & 5.079 .987 .000 \\
\hline
\end{tabular}

